
Acta Universitatis Nicolai Copernici • Pedagogika XXXIII/2017

Nauki Humanistyczno-Społeczne • Zeszyt 438

DOI: http://dx.doi.org/10.12775/AUNC_PED.2017.002

Katarzyna Dormus

Uniwersytet Pedagogiczny w Krakowie

\title{
GALicyjSKa PRASA PEDAgOgiczNA \\ JAKO ŹRÓDLO WIEDZY O ROZWOJU POLSKIEJ MYŚLI PEDAGOGICZNEJ - STAN BADAŃ, POSTULATY
}

\begin{abstract}
Doczątki polskiego czasopiśmiennictwa pedagogicznego przypada- ją na pierwszą połowę wieku XIX. W tym bowiem stuleciu miał miejsce intensywny rozwój prasy, co związane było z kształtowaniem się w Europie nowoczesnego społeczeństwa przemysłowego. Czynniki takie, jak: wzrost poziomu wykształcenia mieszkańców Europy, stale rosnący popyt na informacje, rozwój techniki, powstawanie dużych aglomeracji miejskich, wreszcie - umacnianie się demokracji parlamentarnej oraz rozwój ruchów politycznych, społecznych i narodowych wpływały na dynamikę rozwoju i różnicowanie się wydawnictw prasowych. Powstanie silnych organizmów państwowych sprawiło, że to właśnie państwo w znacznie większym niż dotąd stopniu zaczęło interesować się rozwojem oświaty. Posiadanie wykształconych i odpowiednio wychowanych obywateli stawało się żywotnym interesem państw, ważnym czynnikiem wpływającym na ich rozwój. Zaczęto kłaść nacisk na rozwój oświaty zinstytucjonalizowanej i objęcie nauczaniem jak największej liczny obywateli. Równocześnie pojawiły się tendencje oddolne - sami obywatele zaczęli dążyć do zdobycia jak
\end{abstract}


najlepszego wykształcenia, ono bowiem warunkowało ich sukces życiowy. Na te zjawiska o charakterze społeczno-politycznym nakładał się niezwykle dynamiczny rozwój nauki, w tym nauk pedagogicznych i psychologicznych, oraz pozytywizm z jego wiarą w moc wykształcenia oraz traktowaniem nauki i oświaty jako panaceum na różne trudności i bolączki ówczesnego świata i społeczeństwa. Czynniki te sprzyjały rozwojowi prasy specjalistycznej poświęconej zagadnieniom oświaty, edukacji, wychowania, szeroko pojętym zagadnieniom pedagogicznym.

Zjawiska te miały wymiar ogólnoeuropejski i objęły również ziemie polskie. Jednak w porównaniu z Europą Zachodnią ${ }^{1}$ polskie czasopisma pedagogiczne pojawiły się niemal o wiek później. Ich genezę można wiązać z oświeceniowym przekonaniem o wpływie kształcenia umysłowego na stan moralny społeczeństwa. W połowie wieku XVIII zaczęto wydawać czasopisma moralne mające na celu wychowywanie społeczeństwa. Jednym z nich był „Monitor”, wychodzący w latach 1765-1785, związany z dworem Stanisława Augusta²

Według Stefana Możdżenia pierwszym polskim pismem o charakterze pedagogicznym był warszawski „Dziennik Towarzystwa Dobroczynności”, który ukazał się w roku 1815, a kolejnym - „Dzieje Dobroczynności Krajowej i Zagranicznej z Wiadomościami ku Wydoskonaleniu Jej Służącymi", organ wileńskiego Towarzystwa Dobroczynności wydawany w latach 1820-1824². „Encyklopedia Pedagogiczna XXI wieku" za pierwsze polskie pismo pedagogiczne uznaje dopiero „Rocznik Instytutów Religijnych i Edukacyjnych” wydawa-

1 Pierwszymi pismami pedagogicznymi były czasopisma angielskie: „Tatler” (1709), „Spectator” (1711), „Guardian” (1713). We Francji jako pierwsze tego typu czasopismo ukazał się w 1789 r. „Journal famille on Livre des Enfantes”, w Niemczech zaś w roku 1801 ukazały się trzy czasopisma o takim charakterze, m.in. „Bibliothek für Pädagogik”.

2 M. Lewartowska-Zychowicz, Czasopisma pedagogiczne, w: Encyklopedia Pedagogiczna XXI wieku, t. 1, red. T. Pilch, Warszawa 2003, s. 565.

3 S. Możdżeń, Czasopisma pedagogiczne $w$ Galicji. Stan i potrzeby badań, w: Z dziejów oświaty $w$ Galicji. Materiały z sesji naukowej zorganizowanej w Łańcucie $w$ dniach 23-25 października 1986 roku na temat: „Stan i potrzeby badań nad dziejami oświaty w Galicji”, red. A. Meissner, Rzeszów 1989, s. 60. 
ny w Królestwie Polskim przez Komisję Rządową Wyznań Religijnych i Oświecenia Publicznego w latach 1824-1830.

Intensywniejszy rozwój pism pedagogicznych nastąpił w latach 40 . XIX w. w zaborze pruskim. W okresie ożywienia kulturalnego, które w tym czasie miało tam miejsce, ukazywały się m.in. pisma o charakterze pedagogicznym, takie jak: „Pismo dla Nauczycieli Ludu” (wydawane łącznie z „Pismem dla Ludu”) w latach 1845-1846, a potem „Kościół i Szkoła” (1846-1848) i wreszcie w latach 1849-1853 „Szkoła Polska" Ewarysta Estkowskiego 4 .

W okresie zaborów sytuacja polityczna rzutowała w sposób zasadniczy na kształt polskiego życia społeczno-kulturalnego oraz nauki i oświaty. Rozwój czasopism pedagogicznych napotykał na wiele problemów, charakterystycznych dla prasy polskiej tego czasu. Tak zatem, dzieląc los całej prasy polskiej, pisma pedagogiczne borykały się nieustannie z problemami finansowymi, trudnościami z zapewnieniem sobie grona stałych współpracowników, częstym brakiem materiałów do publikacji, a wreszcie ze znalezieniem czytelników, ponieważ nawyk czytania czasopism dopiero się w polskim społeczeństwie rodził5. Prasa polska tego czasu, także pedagogiczna, ukazywała się w ramach porządków prawnych i politycznych trzech państw zaborczych. Relatywnie najkorzystniejsze warunki panowały w zaborze austriackim, ze względu na obowiązujące w Austrii liberalne prawo prasowe ${ }^{6}$ oraz uzyskanie przez Galicję autonomii w roku 1867, dzięki której społeczeństwo polskie zyskało cały szereg swobód obywatelskich i narodowych. Barierą był natomiast niski poziom zamożności oraz wykształcenia i kultury społeczeństwa galicyjskiego.

${ }^{4}$ M. Lewartowska-Zychowicz, dz. cyt., s. 565.

${ }^{5}$ F. Filipowicz, Zarys rozwoju polskiego czasopiśmiennictwa pedagogicznego, w: Czasopiśmiennictwo pedagogiczne w Polsce Ludowej, red. tenże, Warszawa 1982, s. 20-21; K. Dormus, Rola czasopism historyczno-oświatowych $w$ kształtowaniu się historii wychowania jako samodzielnej dyscypliny naukowej, „Rozprawy z Dziejów Oświaty” 2013, s. 27-33.

6 Austriackie prawo prasowe działało na podstawie ustawy prasowej z 17 XII 1862 r. Konstytucja grudniowa (1867) gwarantowała wolność prasy w granicach obowiązującej ustawy i znosiła system koncesyjny. Przepisy i praktyka austriackiego prawa prasowego liberalizowały się w miarę upływu czasu. 
W Austrii czasopisma pedagogiczne pojawiły się wraz z nastaniem ery konstytucyjnej. Dyskusja nad reformą oświaty trwająca od roku 1865, powołanie Rady Szkolnej Krajowej oraz prowadzenie nowej ustawy szkolnej w roku 1867, jak pisze Antoni Karbowiak, rozbudziło w społeczeństwie polskim różne nadzieje. „Po ostrej zimie nastała dla pedagogiki narodowej polskiej wiosna pełna rojeń”. Tymczasem „niwa pedagogiczna" była zaniedbana, wymagała wytężonej pracy i w tej atmosferze zrodziła się stąd potrzeba założenia czasopisma poświęconego sprawom oświaty i wychowania?.

W miarę rozwoju szkolnictwa publicznego i wzrostu liczebnego nauczycieli, budzenia się ich świadomości zawodowej, powstania warunków dla rozwoju publicznej dyskusji nad problemami szkolnictwa, prasa pedagogiczna rozwijała się coraz intensywnej. Dodatkowy bodziec stanowiły docierające z Zachodu informacje o nowych prądach pedagogicznych, takich jak na przełomie XIX i XX w. nowego wychowania ${ }^{8}$.

Celem rodzącej się prasy pedagogicznej było popularyzowanie wiedzy pedagogicznej, upowszechnianie dorobku polskiej nauki i oświaty, podnoszenie poziomu oświatowo-kulturalnego narodu. Pisma te służyły rozwojowi teorii i praktyki wychowawczej, inspirowały i stanowiły pomoc dla wychowawców, rodziców, działaczy oświatowych, a zwłaszcza dla nauczycieli, co było szczególnie ważne wobec niskiego poziomu nauczania w seminariach i nienajlepszego przygotowania nauczycieli ludowych. Spełniały zatem wielorakie funkcje: informowały, dawały praktyczne wskazówki, wzbogacały wiedzę pedagogiczną i metody wychowania, mobilizowały i aktywizowały. Propagowały nowe prądy w pracy nauczycielskiej i wychowawczej oraz pomagały dostosować je do warunków i potrzeb polskiej szkoły. Uczyły dostrzegać związki pomiędzy wychowaniem a życiem polityczno-społecznym i gospodarczym oraz, co szczególnie istotne było w warunkach niewoli, służyły zachowaniu tradycji i umacnianiu tożsamości narodowej.

\footnotetext{
7 A. Karbowiak, Polskie czasopisma pedagogiczne, Warszawa 1912, s. 29.

8 S. Możdżeń, dz. cyt., s. 59; F. Filipowicz, dz. cyt., s. 20-21.

9 F. Filipowicz, dz. cyt., s. 20-21.
} 
Przyjmując periodyzację dokonaną przez Andrzeja Meissnera, ich rozwój można podzielić na trzy fazy. Pierwsza z nich zaczęła się pod koniec lat 60. XIX w. wraz z nastaniem autonomii. Sprawy reformy oświaty, która weszła wówczas w fazę ostatecznych rozstrzygnięć, sprawiły, że nastąpiła znaczna aktywizacja społeczeństwa polskiego, co z kolei rodziło potrzebę dyskusji i wymiany myśli. W takich warunkach rodziły się pomysły zakładania pierwszych czasopism pedagogicznych: „Tygodnika Szkolnego”, „Szkoły” czy „Szkółki Wiejskiej”10.

W tym okresie powstały też najznaczniejsze - nie tylko galicyjskie, ale też w ogóle polskie - pisma pedagogiczne. W roku 1868 zaczęła wychodzić „Szkoła”, ukazująca się do roku 1939, stanowiąca - ze względu na długi okres ukazywania się, liczący 71 lat - prawdziwy ewenement $\mathrm{w}$ historii prasy pedagogicznej. Od $1871 \mathrm{r}$. była organem Towarzystwa Pedagogicznego. Pismo wpierw miało charakter ogólnopedagogiczny, później koncentrowało się na oświacie powszechnej i szkolnictwie ludowym.

W roku 1885 powstało „Muzeum”, również wychodzące aż do wybuchu II wojny światowej. Było pierwszym pismem o charakterze naukowym, a jako organ Towarzystwa Nauczycieli Szkół Wyższych, koncentrowało się na problemach nauczania na stopniu średnim. Do lat 90. XIX w. pojawiły się jeszcze dwa nowe pisma: „Przewodnik Gimnastyczny Sokół” oraz „Głos nauczycielski”.

Drugi etap rozwoju galicyjskiej prasy pedagogicznej przypadał na lata 90. XIX w. W tym okresie nastąpiło duże ożywienie ruchu nauczycielskiego oraz zintensyfikowanie działalności Rady Szkolnej Krajowej. Ambicją i potrzebą rozwijających się wówczas organizacji nauczycielskich oraz towarzystw oświaty pozaszkolnej czy kulturalno-oświatowych stało się posiadanie własnego organu prasowego, służącego prezentowaniu założeń ideowo-programowych. Czasopisma pomagały wpływać na świadomość społeczną, stawały się zatem na-

10 A. Meissner, Polskie czasopisma pedagogiczne w Galicji, w: Myśl edukacyjna w Galicji 1772-1918. Ciągłość $i$ zmiana, red. Cz. Majorek, A. Meissner, Galicja i jej dziedzictwo, t. 8, Rzeszów 1996, s. 135; tenże, Źródła drukowane do dziejów oświaty $w$ Galicji, w: Źródła $w$ badaniach naukowych historii edukacji, red. W. Szulakiewicz, Toruń 2003, s. 70. 
rzędziem swoistej propagandy. W tym okresie pojawiło się aż 12 nowych tytułów, m.in.: „Szkolnictwo Ludowe”, „Światło”, „Dwutygodnik Katechetyczny” (potem „Dwutygodnik Katechetyczny i Duszpasterski”), „Powściągliwość i Praca”, „Przegląd Gimnastyczny”, „Gazeta Nauczycielska”, „Oświata”, „Rodzina i Szkoła”.

Trzecia faza rozwoju miała miejsce na początku wieku XX, zwłaszcza po roku 1905, co związane było z ożywieniem nastrojów politycznych i narodowych wywołanych rewolucją i strajkami szkolnymi w Królestwie Polskim. W tym czasie pojawiły się aż 22 nowe czasopisma, m.in. „Miesięcznik TSL” (potem „Przewodnik Oświatowy”), „Gazeta Szkolna”, „Reforma Szkolna”, „Głos Nauczycielstwa Ludowego”, „Szkoła Przyszłości”, „Czasopismo Pedagogiczne” czy „Ruch Pedagogiczny"11.

Ogółem w Galicji wydawano kilkadziesiąt czasopism pedagogicznych $^{12}$ o różnym czasie ukazywania się. Pism ukazujących się przez kilkadziesiąt lat było niewiele. Do grupy tej należały: „Szkoła” (1868-1939) (będąca absolutną „rekordzistką” w tej dziedzinie), a następnie „Muzeum” (1885-1939), „Powściągliwość i Praca” (1898-1931) oraz „Miesięcznik TSL” (1901-1939). Bywały też takie, które nie przetrwały nawet roku. Dłużej ukazywały się te, które były pismami stowarzyszeń, niektóre z nich korzystały nawet z różnych subwencji, co ułatwiało im byt. W najtrudniejszej sytuacji były czasopisma wydawane przez osoby prywatne. Głównymi ośrodkami wydawniczymi były Lwów i Kraków, choć wydawano pisma też w mniejszych miastach i miejscowościach ${ }^{13}$.

Czasopisma pedagogiczne stanowią dla historyków wychowania interesujący, a niekiedy wręcz niezastąpiony materiał źródłowy do poznania dziejów polskiego szkolnictwa i historii myśli pedagogicznej. Jak pisze Iwonna Michalska, wszystkie one są „wydawnictwami, które obfitują w bogactwo materiałowe, umożliwiające odtwarzanie minionych faktów, zdarzeń, poglądów i opinii na tematy edukacyj-

\footnotetext{
11 A. Meissner, Polskie czasopisma..., s. 136-137, 139.

12 Wg S. Możdżenia - 55, wg A. Meissnera - 41.

13 S. Możdżeń, dz. cyt., s. 63.
} 
no-wychowawcze"14. Jak z kolei zauważa Stefan Możdżeń, w prasie pedagogicznej „odbija się echem życie pedagogiczne, za jej pośrednictwem rozpowszechniają się nowe idee edukacyjne, docierając do środowisk stojących z dala od ośrodków nauki. Na łamach czasopism pedagogicznych omawiane bywają aktualne zagadnienie wychowawcze, tu ścierają się poglądy i idee"15.

Specyfika czasopism pedagogicznych jako źródeł do historii wychowania polega na przekazywaniu bieżących informacji, rejestrowaniu tego, co dzieje się tu i teraz w konkretnym otoczeniu i konkretnym czasie historycznym oraz sytuacji społecznej. Dzięki nim można uchwycić zjawiska i wydarzenia krótkotrwałe, które szybko przemijając nie pozostawiają za sobą innych śladów. Artykuły i informacje zamieszczane na łamach tych czasopism pokazują zmienność rzeczywistości społecznej, a - jak zauważa Iwonna Michalska: „(...) to, co dla czytelnika periodyków staje się z czasem nieaktualne, dla badacza przeszłości edukacyjnej ma istotne znaczenie"16.

Czasopisma stanowiły również ważne forum wymiany poglądów i opinii. Żadne inne źródło nie oddaje tak dobrze zjawiska ścierania się poglądów, kształtowania nowych, pozwalając równocześnie wyodrębnić poglądy i wartości trwałe oraz ogólnie akceptowane. Jak zauważa Andrzej Meissner, czasopisma te umożliwiły rozwój rodzimej pedagogiki i psychologii. Stanowiły inspirację do prowadzenia badań nad dziećmi, zachęcały do podejmowania dyskusji nad palącymi problemami, nad projektami reform szkolnych, służyły podnoszeniu kultury pedagogicznej ${ }^{17}$.

Z tych wszystkich względów prasa pedagogiczna jest znakomitym źródłem pozwalającym odtworzyć proces kształtowania się polskiej myśli pedagogicznej, świadomości edukacyjnej społeczeństwa, formowania się środowiska nauczycieli i świadomości zawodowej tej grupy

14 I. Michalska, Czasopiśmiennictwo $w$ badaniach historyczno-pedagogicznych, w: Badania historyczne w pedagogice. Konteksty źródłowe, red. W. Szulakiewicz, Pedagogika Toruńska, t. 5, Toruń 2015, s. 14.

15 S. Możdżeń, dz. cyt., s. 59.

16 I. Michalska, dz. cyt., s. 23.

17 A. Meissner, Polskie czasopisma..., s. 145. 
zawodowej, wreszcie pozwala uchwycić obraz funkcjonowania szkoły. Zakres poruszanych w niej tematów jest bardzo rozległy. Wśród najważniejszych i najczęściej omawianych są: kwestie związane z kształtowaniem się zawodu nauczycielskiego, kształceniem nauczycieli i ich przygotowaniem zawodowym, kwestie metodyczne, dydaktyczne i wychowawcze dotyczące organizacji i sposobu funkcjonowania placówek szkolnych i pozaszkolnych instytucji oświatowych. Pisma pedagogiczne, takie jak np.: „Szkolnictwo”, „Gazeta Szkolna”, „Głos Nauczycielstwa Ludowego", były miejscem, w którym społeczeństwo usiłowało podjąć dyskusję z władzami oświatowymi o stanie szkolnictwa i możliwościach jego zmiany.

Pojawiało się też omówienie i refleksja na temat ugruntowanych już w Europie koncepcji pedagogicznych, jak np. herbartyzmu, czy nowych kierunków rozwijających się w ramach nurtu nowego wychowania. Treści związane $\mathrm{z}$ herbartyzmem poruszane były na łamach np. „Ruchu katolickiego”, „Dwutygodnika katolickiego” czy „Miesięcznika Katechetycznego i Wychowawczego”. Z kolei pisma takie, jak: „Muzeum”, „Szkoła”, „Reforma szkolna”, „Ruch higieniczny”, „Ruch pedagogiczny”, „Rodzina i szkoła”, „Szkoła przyszłości” czy „Wolna szkoła” popularyzowały kierunki związane z nowym wychowaniem, upowszechniały koncepcje i idee pedagogiki zachodnioeuropejskiej i amerykańskiej (np.: koncepcje Johna Dewey’a, metodę Montessori, slöjd, badania psychologiczne, pedologię) $)^{18}$.

W szerszym aspekcie historia czasopism pedagogicznych stanowi element dziejów prasy polskiej, pozwala odtworzyć zjawisko kształtowania się nawyków czytelniczych, rynku wydawniczego, a tym samym jest elementem studiów nad szeroko pojmowaną kulturą narodową.

Galicyjska prasa pedagogiczna ze względu na bogactwo i różnorodność tytułów, długi okres rozwoju przypadający na czasy bardzo ważne dla kształtowania się świadomości i tożsamości narodowej Polaków, w tym też świadomości edukacyjnej, stanowi źródło nie tylko bogate i interesujące, lecz niestety słabo wykorzystane. Brakuje bowiem wciąż szeroko zakrojonych, gruntownych i systematycznych badań nad galicyjską prasą pedagogiczną tak w aspekcie jej dziejów,

18 A. Meissner, Źródła drukowane..., s. 71. 
typologii, cech charakterystycznych, jak i pod względem merytorycznym dotyczącym treści pedagogicznych, pedeutologicznych, historyczno-oświatowych, a nawet społecznych w niej zawartych.

Stan badań nie przedstawia się zbyt imponująco. Brakuje zarówno opracowań o charakterze syntetycznym dotyczących tej prasy jako całości, ale również opracowań poszczególnych tytułów czy zagadnień poruszanych na łamach tej prasy. Świadczyć może o tym fakt, iż praca Antoniego Karbowiaka dotycząca dziejów polskiej prasy pedagogicznej, w tym galicyjskiej, wydana w roku 1912, mimo wielu braków i niedoskonałości, wciąż stanowi jedno z podstawowych opracowań, o czym świadczy liczba powołań pojawiających się współcześnie w publikacjach naukowych. Z początku wieku XX pochodzą też dwa artykuły, w których wspominano o pismach galicyjskich, napisane przez znakomitych nauczycieli i pedagogów Józefa Ciembroniewicz i Henryka Rowida. Ciembroniewicz jest autorem artykułu „Czasopisma pedagogiczne polskie” zamieszczonego w "Przeglądzie Pedagogicznym” w roku 1903 (nr 24), zaś Rowid - o ponad 10 lat późniejszej publikacji „Polskie czasopiśmiennictwo pedagogiczne” opublikowanej w „Ruchu Pedagogicznym" (1919 nr 9-10). Po ukazaniu się tych publikacji nastąpiła długa przerwa. Jeszcze w roku 1963 Wiktor Czerniewski stwierdzał, iż wciąż jest „brak monografii o czasopismach pedagogicznych w Polsce, jak i brak bibliografii ich zawartości”19.

Więcej opracowań na ten temat pojawiło się w latach 80. i 90. XX w. oraz w ostatnim dziesięcioleciu. O galicyjskiej prasie pedagogicznej pisali prasoznawcy i historycy oświaty, prezentując - z racji uprawianej dyscypliny - różne punkty widzenia.

Historycy prasy długo pomijali problem prasy pedagogicznej. Próżno szukać haseł dotyczących czasopism pedagogicznych w wydanej w latach 70. Encyklopedii wiedzy o prasie ${ }^{20}$. W pochodzącej z tego samego czasu Historii prasy polskiej, w rozdziałach dotyczących dziejów prasy galicyjskiej, prasa pedagogiczna praktycznie nie istnieje. We fragmencie dotyczącym galicyjskich czasopism naukowo-technicz-

19 W. Czerniewski, Rozwój dydaktyki Polskiej w latach 1918-1954, Warszawa 1963, s. 21.

20 Encyklopedia wiedzy o prasie, red. J. Maślanka, Wrocław 1976. 
nych wymienione jest „Muzeum” oraz „Oświata Ludu” i „Przewodnik Oświatowy”. Te dwa ostatnie opatrzone komentarzem, iż „dobre były niektóre periodyki poświęcone metodyce popularyzacji wiedzy oświaty prowadzone prze wyspecjalizowane organizacje [...]"21. Ponadto wymienione jest jeszcze „Szkolnictwo Ludowe”, ale w kontekście pism ukazujących się w małych ośrodkach, oraz „Miesięcznik Pedagogiczny” i „Ruch Pedagogiczny” jako pisma wznowione po I wojnie ${ }^{22}$.

Pewne zainteresowanie prasoznawców galicyjską prasą pedagogiczną nastąpiło dopiero w latach 80 . Na ten temat pisał Franciszek Filipowicz ${ }^{23}$, a zwłaszcza Jerzy Jarowiecki, zasłużony badacz dziejów prasy polskiej, który poświęcił galicyjskiej prasie pedagogicznej polskiej i ukraińskiej kilka artykułów ${ }^{24}$.

Spośród historyków wychowania zagadnieniem tym zajmowali się Adolf Molak, ${ }^{25}$ a przede wszystkim Stefan Możdżeń ${ }^{26}$ i Andrzej Meissner ${ }^{27}$. Na przestrzeni ostatniego półwiecza opublikowano też sze-

21 J. Myśliński, Prasa polska w Galicji doby autonomicznej (1867-191), w: Historia prasy polskiej, t. 2: Prasa polska w latach 1864-1918, red. J. Łojek, Warszawa 1976, s. 114-173.

22 Tamże, s. 134.

23 F. Filipowicz, dz. cyt.

24 J. Jarowiecki, Czasopisma pedagogiczne $w$ Polsce, w: Encyklopedia pedagogiczna, red. W. Pomykało, Warszawa 1993, s. 81-82; tenże, Czasopisma pedagogiczne $w$ Polsce. Historia i teraźniejszość, w: tenże, Studia nad prasą polska XIX i XX wieku, t. 1, Kraków 1997; tenże, Prasa lwowska $w$ dobie popowstaniowej, w: tenże, Studia nad prasa..., t. 1; tenże, Polska i ukraińska prasa pedagogiczna $w$ Galicji w okresie autonomii w latach 1867-1918, w: Kraków-Lwów. Książki, Czasopisma, biblioteki XIX i XX wieku, t. 10, red. H. Kosętka, G. Wrona i G. Nieć, Kraków 2011; tenże, Dzieje prasy polskiej we Lwowie do 1945, Kraków-Wrocław 2008, s. 154-155; tenże, Czasopiśmiennictwo pedagogiczne we Lwowie w okresie autonomii galicyjskiej, w: Społeczeństwo, kultura, inteligencja, Studia historyczne ofiarowane profesor Irenie Homoli-Skapskiej, red. E. Osman, G. Nieć, Kraków 2001, s. 385-406.

25 A. Molak, Z dziejów polskiej prasy pedagogicznej, „Nowa Szkoła” 1961, nr 10, s. 40.

26 S. Możdżeń, J. Musiał, Bibliografia polskich czasopism pedagogicznych (do 1979 r.), Kielce 1981; S. Możdżeń, dz. cyt.

27 A. Meissner, Polskie czasopisma pedagogiczne Lwowa i Krakowa w okresie autonomii galicyjskiej w latach 1868-1918, w: Książki, czasopisma, biblioteki Kra- 
reg (około 20) artykułów lub rozdziałów w większych opracowaniach poświęconych polskiej prasie pedagogicznej w Galicji. Odniesiono się w nich do 12 spośród galicyjskich czasopism pedagogicznych, a część publikacji dotyka problematyki związanej z myślą pedagogiczną. Najwięcej artykułów, bo aż 6, dotyczy „Szkoły”, jej wkładu w polską teorię i praktykę pedagogiczną, poruszane są też zagadnienia związane z wychowaniem patriotycznym czy kwestiami pedeutologicznymi ${ }^{28}$. Pięć artykułów odnosi się do „Muzeum” i dotyczą historii czasopisma oraz recepcji zachodniej myśli pedagogicznej na jego łamach ${ }^{29}$. Również 3 artykuły poświęcono „Ruchowi Pedagogicznemu”, jego dziejom oraz popularyzacji idei nowego wychowania ${ }^{30}$. Pojedyncze artykuły

kowa i Lwowa XIX i XX wieku, red. J. Jarowiecki, Kraków 1993; tenże, Polskie czasopisma pedagogiczne..., s. 133-148; tenże, Źródła drukowane..., s. 69-72.

28 W. Bobrowska-Nowak, Problemy pedagogiczne na łamach „Szkoły”, „Przegląd Historyczno-Oświatowy” 1971, nr 2, s. 261-277; A. Stopińska-Pająk, Wkład czasopisma „Szkoła” w rozwój myśli pedagogicznej, w: Myśl edukacyjna w Galicji..., s. 169-180; A. Świątek, Problem patriotycznego wychowania ludu na łamach lwowskiej „Szkoły” w czasach autonomii galicyjskiej, w: Czasopiśmiennictwo XIX i początków XX wieku jako źródło do historii edukacji, pod red. I. Michalskiej i G. Michalskiego, Łódź 2010, s. 169-184; A. Wałęga, Nauczyciele galicyjscy w świetle „Szkoły”, w: Badania biograficzne $w$ pedagogice. Studia źródłowe i bibliograficzne, red. W. Szulakiewicz, Toruń 2015, Pedagogika Toruńska, t. 6, s. 199-212; taż, Galicyjska „Szkoła” jako przykład czasopisma pedagogicznego okresu zaborów, „Acta Universitatis Nicolai Copernici. Nauki humanistyczno-społeczne" 2013, z. 421; taż, Dziedzictwo polskiej teorii i praktyki pedagogicznej na kartach „Szkoły”, w: Polskie dziedzictwo pedagogiczne. Rozważania o ideach $i$ instytucjach, red. J. Falkowska, Pedagogika toruńska, t. 7, Toruń 2016, s. 59-76.

29 F. Majchrowicz, Czterdziestoletni jubileusz czasopisma „Muzeum”, dodatek do „Muzeum” 1925; K. Sochoniewicz, Czterdziestolecie „Muzeum” 1885-1925, dodatek do „Muzeum” 1925; T. Gumuła, Czasopismo „Muzeum” organ TNSW, w: Z dziejów oświaty w Galicji..., s. 139-150; taż, Z dziejów „Muzeum” 1885-1935. W setna rocznice założenia czasopisma, w: Z historii szkolnictwa i myśli pedagogicznej w Polsce (1773-1939), pod red. S. Walasek, Wrocław 1990, s. 169-179; K. Szmyd, Zachodnia myśl pedagogiczna i jej postulaty reform szkoty średniej na łamach kwartalnika „Muzeum” (1890-1914), w: Pedagogika nowego wychowania w Polsce u schyłku XIX i w pierwszej połowie XX wieku, Galicja i jej dziedzictwo, t. 14, red. A. Meissner, C. Majorek, Rzeszów 2000, s. 193-204.

30 W. Wojtyński, „Ruch pedagogiczny” od swego powstania w roku 1912 do chwili obecnej, „Ruch Pedagogiczny” 1965, nr 5/6; tenże, 60-lecie „Ruchu Pedago- 
dotyczą czasopism takich, jak: „Kurenda Szkolna”31 , „Rodzina i Szkoła”32, „Wolna Szkoła”33, „Gazeta Szkolna”"34, „Szkolnictwo Ludowe”35, „Wiedza dla Wszystkich”36, „Czasopismo Pedagogiczne”37, „Szkolnictwo"38 oraz „Głos Nauczycielstwa Ludowego"39. Przedstawione zestawienie zapewne nie jest kompletne i nie rości sobie pretensji do bycia wyczerpującym wykazem bibliograficznym.

Warto przytoczyć też przykłady opracowań wykorzystujących szeroko galicyjskie czasopisma pedagogiczne jako źródło do analizy dziejów polskiej myśli pedagogicznej. Do opracowań takich należą np. artykuły Czesława Majorka oraz Andrzeja Meissnera poświęcone polskiej myśli pedagogicznej w zaborze austriackim oraz Andrzeja Ładyżyńskiego, w którym została omówiona kwestia zainteresowania czasopism pedagogicznych szkołami obcymi ${ }^{40}$.

gicznego”, „Ruch Pedagogiczny” 1972, nr 4, s. 391-400; H. Raczek, Idee „Nowego Wychowania” na łamach „Ruchu Pedagogicznego”, w: Pedagogika nowego wychowania..., s. 205-210.

${ }^{31}$ B. Jaśkiewicz, „Kurenda Szkolna” (1857-1868) - pismo diecezji tarnowskiej poświęcone szkolnictwu ludowemu, w: Myśl edukacyjna w Galicji..., s. 149-155.

${ }^{32}$ K. Jakubiak, Rodzina i wspótpraca domu ze szkoła $w$ świetle publicystyki pedagogicznej „Rodziny i Szkoły” (1896-1913), w: Myśl edukacyjna w Galicji...

${ }^{33}$ B. Pleśniarski, Walka „Wolnej Szkoty” o laicyzację wychowania, „Przegląd Historyczno-Oświatowy" 1961, nr 4, s. 458-468.

${ }^{34}$ H. Kramarz, Krakowska „Gazeta szkolna” (1902-1913) i geneza jej radykalizmu w krytyce galicyjskiej oświaty ludowej, w: Kraków-Lwów. Książki, czasopisma, biblioteki XIX i XX wieku, t. 5, pod red. H. Kosętki, G. Wrony, G. Niecia, Kraków 2001, s. 545-552.

35 E. Smajdor, „Szkolnictwo Ludowe” w Nowym Saczu (lata 1891-1913) i jego rola w ksztattowaniu ruchu nauczycieli, „Rocznik Sądecki' 1968, s. 165-209.

${ }^{36}$ K. Wojciechowski, O „Wiedzy dla wszystkich” (Lwów 1899), „Oświata Dorosłych" 1969, nr 1, s. 12-13.

37 J. Wojtal, Lwowskie "Czasopismo Pedagogiczne” z 1896 r. - propagator pedagogiki narodowej, „Rozprawy z Dziejów Oświaty” 1984, s. 91-149.

${ }_{38}$ S. Truchim, E. Podgórska, Z początków zawodowego ruchu nauczycielskiego, Warszawa 1958.

${ }^{39}$ E. Podgórska, Krajowy Związek Nauczycielstwa Ludowego w Galicji 1905-1918, Warszawa 1973.

40 C. Majorek, Polska myśl pedagogiczna w zaborze austriackim, „Przegląd Historyczno-Oświatowy” 1992, nr 3-4; A. Meissner, Wkład Galicji w rozwój nauk 
Tak skromny stan badań powoduje, iż już najbardziej podstawowe sprawy dotyczące czasopiśmiennictwa pedagogicznego nastręczają trudności i problemów, poczynając od definicji „czasopisma pedagogicznego" i jego odniesienia do galicyjskiej prasy pedagogicznej, co z kolei skutkuje zaszeregowaniem lub odrzuceniem pewnych czasopism do grupy pism pedagogicznych. Ustalenie, czy dany periodyk jest pismem pedagogicznym może napotykać na trudności z tego względu, iż formułowane są różne definicje. Wincenty Okoń za czasopisma pedagogiczne uznaje te „ukazujące się regularnie wydawnictwa ciągłe, które zajmują się sprawami oświaty i wychowania, spełniając ważną rolę $\mathrm{w}$ rozwijaniu nauk pedagogicznych i upowszechnianiu kultury pedagogicznej”'11. Definicja ta jest niemal dosłownie powtórzona w Encyklopedii Pedagogicznej XXI wieku ${ }^{42}$.

Franciszek Filipowicz przyjmuje, że czasopisma te mają uwzględniać w całości sprawy kształcenia i wychowania, ale zwraca uwagę na kryteria dodatkowe, jakimi są wydawca pisma (najczęściej instytucja, zrzeszenie lub organizacja pracująca w dziedzinie teorii i praktyki pedagogicznej) oraz adresat, gdyż „adresowane [są one - K. D.] do osób zawodowo zajmujących się działalnością dydaktyczno-wychowawczą i opiekuńczą lub też z tymi osobami współpracującymi”43.

Jerzy Jarowiecki wprowadza do tej definicji nowy element, jakim jest ich „ograniczona częściowo aktualność i uniwersalność" ${ }^{4}$.

Stefan Możdżeń i Julia Musiał w swej bibliografii czasopism pedagogicznych przyjęli bardzo szeroką definicję czasopisma pedagogicznego, zaliczyli bowiem do prasy pedagogicznej kurendy, sprawozdania Rady Szkolnej Krajowej i dzienniki urzędowe, czyli „czasopisma urzędowe” o charakterze normatywnym lub sprawozdawczym ${ }^{45}$; Andrzej

pedagogicznych, w: Nauka i oświata, red. A. Meissner, J. Wyrozumski, Galicja i jej dziedzictwo, t. 3, Rzeszów 1995; A. Ładyżyński, Galicyjskie zainteresowania szkołami obcymi $w$ dobie autonomii ( $w$ świetle czasopiśmiennictwa pedagogicznego), w: Myśl edukacyjna w Galicji..., s. 181-189.

41 W. Okoń, Nowy słownik pedagogiczny, Warszawa 2004, s. 68.

${ }^{42}$ M. Lewartowska-Zychowicz, dz. cyt., s. 564.

43 F. Filipowicz, dz. cyt., s.15.

44 Encyklopedia pedagogiczna, red. W. Pomykało, Warszawa 1993, s. 79.

45 S. Możdżeń, Czasopisma pedagogiczne..., s. 63. 
Meissner wykluczył je jednak z grupy pedagogicznych, przyjmując, że stanowią one oddzielną grupę „czasopism urzędowych”. Pozostawił natomiast te periodyki, które „wprawdzie nie były organami instytucji czy organizacji oświatowych, lecz w szerokim zakresie uwzględniały problematykę edukacyjną", jak np. czasopisma dotyczące wychowania fizycznego i higieny szkolnej" ${ }^{46}$.

Brak jednoznacznej definicji utrudnia sporządzenie kompletnego spisu polskich czasopism pedagogicznych ukazujących się w Galicji, a ustalenie takiego wykazu byłoby dla badaczy niezwykle przydatne. W 1912 r. Antoni Karbowiak wymieniał tylko 15 tytułów, które uznawał za pedagogiczne. Andrzej Meissner do grupy polskich czasopism pedagogicznych ukazujących się w Galicji zalicza 41 tytułów, zaś Stefan Możdżeń - aż $55^{47}$.

Nie tylko sporządzenie wykazu czasopism, ale też ustalenie początków czasopiśmiennictwa pedagogicznego w Galicji przysparza problemów, a badacze nie są w tej kwestii ze sobą zgodni. Antoni Karbowiak za pierwsze pismo pedagogiczne w Galicji uznał „Szkołę”"48. Takie ustalenie przyjęto też w Encyklopedii Pedagogicznej XXI wieku ${ }^{49}$. Pogląd ten podziela Stefan Możdżeń, choć obok „Szkoły” wymienia „Tygodnik Szkolny" wydawany w Nowym Sączu (1868). Zwraca on również uwagę na ukazujący się jeszcze wcześniej w latach 1862-1864 w Cieszynie „Rocznik Ewangelicki”, będący pismem poświęconym sprawom kościoła i szkoły ${ }^{50}$. Andrzej Meissner jako pierwszy wymienia periodyk „Szkółka Parafialna” wydawany w Sanoku w latach 1857-1869, a więc w okresie jeszcze przedautonomicznym. O piśmie tym jednak nie posiadamy żadnych szerszych informacji ${ }^{51}$.

Problemy z ustaleniem wykazu czasopism wpływają też na rozważania i ustalenia dotyczące ich rozmieszczenia czy klasyfikacji ${ }^{52}$.

46 A. Meissner, Polskie czasopisma..., s. 139.

47 Tamże, s. 140; S. Możdżeń, Czasopisma pedagogiczne..., s. 63.

48 A. Karbowiak, dz. cyt., s. 29.

49 M. Lewartowska-Zychowicz, dz. cyt., s. 566.

50 S. Możdżeń, Czasopisma pedagogiczne..., s. 62.

51 A. Meissner, Źródła drukowane..., s. 69; tenże, Polskie czasopisma..., s. 133.

52 Tenże, Polskie czasopisma..., s. 140, 143; S. Możdżeń, Czasopisma pedagogiczne..., s. 63. 
Szczególnie kwestia klasyfikacji nie jest prosta, ponieważ w Galicji nie istniała daleko posunięta specjalizacja tematyczna jak np. w Niemczech. Polskie czasopisma kształtowały się powoli, ciągle ewoluując i zmieniając swój profil, czego przykładem jest „Szkoła” wychodząca wpierw jako pismo ogólnopedagogiczne, a potem nastawione na problematykę szkolnictwa ludowego.

Jako przykład różnych klasyfikacji można podać np. podział dokonany przez Antoniego Karbowiaka, który osobno wymienia "Szkołę” i „Muzeum”, a następnie czasopisma opozycyjne wobec władz oświatowych, czasopisma o charakterze umiarkowanym, czasopisma fachowe nauczycieli religii, wreszcie związane z kręgiem reformy szkolnej53. Andrzej Meissner proponuje dwie klasyfikacje - merytoryczną, a więc dokonaną pod kątem preferowanej problematyki i przynależności organizacyjnej oraz klasyfikację przyjmującą kryterium wydawcy. Klasyfikacja merytoryczna obejmuje czasopisma: ogólnopedagogiczne, specjalistyczno-pedagogiczne, przedmiotowo-metodyczne, a klasyfikacja, biorąc pod uwagę kryterium wydawcy czasopisma: związkowe, towarzystw kulturalno-oświatowych, wydawane przez administrację świecką i kościelną, wreszcie prywatne ${ }^{54}$.

Zapewne pogłębione badania nad prasą pedagogiczną, zwłaszcza nad zawartością czasopism, niewątpliwie pomogłyby poczynić odpowiednie ustalenia w zakresie ich podziału i klasyfikacji. Analiza zawartości pozwoliłaby także ustalić szczegółowy zakres poruszanych tematów, dominujące trendy oraz tendencje, a zatem pozwoliłaby w pełni ocenić wpływ tej prasy na rozwój myśli pedagogicznej i praktyki edukacyjnej.

Pogłębione badania nad polską prasą pedagogiczną w Galicji są niezbędne, bo - jak ocenia Andrzej Meissner - „dokonanie całościowej oceny czasopiśmiennictwa pedagogicznego na obecnym etapie badań nie jest jeszcze w pełni możliwe. Wymaga to przeprowadzenia charakterystyki wydawnictw periodycznych [...]"55. Najistotniejsze zatem byłoby opracowanie monografii poszczególnych czasopism, sporządzenie bi-

\footnotetext{
53 A. Karbowiak, dz. cyt.

54 A. Meissner, Polskie czasopisma..., s. 140-143.

55 Tamże, s. 145.
} 
bliografii ich zawartości oraz przeprowadzenie szczegółowych badań, dotyczących prezentowanych na łamach tej prasy koncepcji pedagogicznych, pod kątem problemowym i charakterystyki poszczególnych czasopism, następnie dokonanie porównań prasy galicyjskiej z prasą pedagogiczną zaboru rosyjskiego, ukazanie jej rozwoju na tle europejskim oraz zbadanie zjawiska przenikania postaw i myśli. Warto byłoby też rozpocząć badania nad czasopismami ukraińskimi i żydowskimi.

Interesującym problemem jest też porównanie ośrodka lwowskiego i krakowskiego w odniesieniu do tezy postawionej przez Andrzej Meissnera, iż „czasopisma lwowskie przyczyniły się do podniesienie poziomu wykształcenia nauczycieli poszczególnych szczebli kształcenia, rozbudziły potrzebę samokształcenia, umożliwiały poznanie rodzimego systemu oświatowego. Odegrały też ważną rolę w kształtowaniu się nauk pedagogicznych, krystalizowaniu się takich dyscyplin, jak np. pedagogika ogólna, dydaktyka, metodyka poszczególnych przedmiotów nauczania w szkole ludowej i średniej, wreszcie historia wychowania. [...] torowały też drogę psychologii, zwłaszcza psychologii dziecka. Z kolei czasopisma krakowskie stały się ważnym narzędziem kształtowania się poglądów społecznych nauczycieli, budzenia ich świadomości i solidarności zawodowej. Stanowiły dla opozycyjnych organizacji nauczycielskich silny nieraz oręż w walce z rodzimą reakcją"

Tylko szeroko zakrojone, szczegółowe badania mogą stanowić podstawę i konieczny warunek dla opracowania monografii czasopiśmiennictwa pedagogicznego w Galicji. Rozległość tematu stanowi niewątpliwie dużą trudność, jednak konieczny materiał jest zachowany i łatwo dostępny. Ponieważ zakres tych badań jest bardzo rozległy, wymaga podjęcia badań zespołowych i to rozłożonych na długi okres czasu. Polskie środowisko historyków wychowania powinno wziąć pod uwagę konieczność powołania odpowiednich zespołów badawczych, działających w ramach grantów czy projektów badawczych. Być może, iż badaniu tej tematyki służyłoby też jej opracowywanie w ramach prac magisterskich czy doktorskich. Polska prasa pedagogiczna w Galicji niewątpliwie stanowi materiał źródłowy tak interesujący i cenny, że podjęcie podobnych badań jest głęboko uzasadnione.

56 Tamże, s. 144. 


\section{Summary}

Polskie czasopisma pedagogiczne w Galicji pojawiły się w epoce autonomicznej. Głównym ich celem było popularyzowanie wiedzy pedagogicznej oraz upowszechnianie dorobku polskiej nauki i oświaty. Dla współczesnych badaczy są znakomitym źródłem pozwalającym odtworzyć proces kształtowania się polskiej teorii i praktyki edukacyjnej. Niestety stan badań nad polską prasą pedagogiczną w Galicji przedstawia się skromnie. Brakuje zarówno opracowań o charakterze syntetycznym, jak i szczegółowych monografii. Postulowane jest zatem rozwijanie szeroko zakrojonych, systematycznych badań w tym zakresie.

Słow a kluc zowe : czasopisma pedagogiczne, Galicja, historia myśli pedagogicznej, stan badań

\section{Summary}

Galician Pedagogical Press as a Source of Insight into the Development of Polish Pedagogical Thought - State of Research, Demands

Polish pedagogical magazines in Galicia started to appear during the times of autonomy. Their main goal was popularization of pedagogical knowledge and the achievements of Polish science and education. For contemporary researchers, these magazines are an excellent way to reconstruct the development of Polish educational theory and practice. Unfortunately, there is only a modest amount of research on Polish pedagogical press in Galicia - both synthetic works and detailed monographs are scarce. As such, there are demands for conducting broad, systematic research on the subject.

Keywords: pedagogical magazines, Galicia, history of pedagogical thought, state of research 
